\title{
A Preliminary Study on the Nicknames of the FIFA National Football Teams
}

WANG FENG (D)

School of Foreign Languages and Cultures, Nanjing Normal University, Nanjing, China

School of Foreign Studies, Yangtze University, Jingzhou, China

ZHANG SHUYUE

School of Foreign Studies, Yangtze University, Jingzhou, China

\section{Chen Cheng}

School of Foreign Languages, Shanghai Ocean University, Shanghai, China

This study examines 315 nicknames of all the 211 FIFA national football teams (NFTs) as of January 2020. A preliminary analysis of these nicknames shows that they have statistically significant differences, suggesting subtle intercultural variation worthy of further investigation. It is hoped that this initial foray into these nicknames will inspire in-depth academic research at the continental and intercontinental levels.

KEYWORDS nicknames, football, soccer, sports, team, FIFA

\section{Introduction}

Football is a global game with tens of millions of fans, and the World Cup is one of the most popular sports tournaments in the world. Each participating national football team (NFT) has a nickname. For example, the France NFT, the champion of the $2 \mathrm{I}^{\text {st }}$ World Cup of the Fédération Internationale de Football Association or FIFA has the nickname Les Bleus 'The Blues', Les Tricolores or L'Equipe Tricolore, 'The Tri-color Team' or the Brazilians of Europe. Croatia's team has two nicknames: Vatreni 'The Blazers' and Kockasti 'The Chequered Ones'. What onomastic strategies do these nicknames reveal? What is behind the different nicknames of these teams? Relevant research includes Franks 
(I982) on the nicknaming of college athletic mascots; Wilson and Skipper (I990) on the nicknames of women professional baseball players; Nuessel (I994) on the nicknames, logos, and mascots of sport teams in North America; and Lavric et al. (2008) and Guirao (2017) who examine a few select NFT nicknames. However, to our knowledge, the nicknames of NFTs have not been previously systemically studied. In this study, we statistically analyzed all the nicknames of the 2I I FIFA NFTs as of January 2020.

In many ways, nicknames provide a richer and more explicit denotation than do given names (Harre 1980). Some of the functions served by nicknames are to break down barriers of formality; increase fan identification; and create a sense of closeness (Lieb I943; Harre I980; McBride I980; Skipper I985). According to Nuessel (I994), nicknames of sport teams refer to "people or objects in the real world with those positive and negative qualities associated with winning or beating an opponent" ( 108$)$. In our study of NFTs, the nicknames are usually descriptive and are given in addition to the official team's official name. As will be shown in this investigation, these nicknames often indicate the team colors, animal symbols, regions, nationalities, and guiding virtues. On the surface, naming the NFTs is driven by the combined basic motivation to identify teams and distinguish them from others. However, NFT nicknaming may be subject to many underlying factors worthy of in-depth study. These factors may involve the population size and ethnic diversity as well as the geographical, political, economic, cultural, and historical backgrounds of the teams involved. The aim of the current study is to contribute to the growing body of literature informing name theory. As Leslie and Skipper (I990) suggest, onomastic theory is in critical need of valid empirical evidence gathered on solid methodological grounds. Towards that end, they recommend that researchers: I) document nicknames and their origins within specific samples; 2) analyze nickname data by positing potential classification categories for the names; and 3) determine the conditions under which the names are used. By taking these steps, it becomes possible to identify the constitutive, preferential, and ad hoc rule-bounded properties of nicknames and nickname use. It is hoped that this preliminary analysis of the nicknames of the NFTs will contribute to this overall goal, and encourage more expansive and comprehensive investigations of these nicknames in future.

\section{Methodology}

The methodology was mainly adopted from Wilson and Skipper (I990). Firstly, the list of nicknames of all the 2I I NFTs was established from Wood (2008), Wikipedia (20I9a), Wikipedia (2019b) and over 200 webpages introducing the NFTs hyperlinked to the latter two. In addition, a Google search was performed for "nickname + National Football Team + a specific team's name" (See the Appendix). The next step was to develop a classification scheme. Ten classification types were derived by analyzing the total 477 terms identified in the 3 I 5 nicknames of the 2 I I NFTs. In Table I, these classification types are represented by letters $\mathrm{A}$ to $\mathrm{J}$ and followed by real-life examples. 


\begin{tabular}{|c|c|c|c|}
\hline No. & $\begin{array}{l}\text { Type } \\
\text { Code }\end{array}$ & $\begin{array}{l}\text { Type of terms in } \\
\text { Nicknames }\end{array}$ & Examples \\
\hline 1 & A & collective & Germany: Die Nationalmannschaft 'The National Team' \\
\hline 2 & $\mathrm{~B}$ & humans & South Africa: Bafana Bafana 'Boys, Boys' \\
\hline 3 & C & colors & France: Les Bleus 'The Blues' \\
\hline 4 & D & virtues & Nigeria: Super Eagles \\
\hline 5 & $\mathrm{E}$ & animals & Ivory Coast: Les Éléphants 'The Elephants’ \\
\hline 6 & $\mathrm{~F}$ & celestial bodies & Ghana: Black Stars \\
\hline 7 & G & natural phenomena & Puerto Rico: El Huracán Azul 'The Blue Hurricane' \\
\hline 8 & $\mathrm{H}$ & regions & Afghanistan: Sirhâi Khorasan 'The Lions of Khorasan' \\
\hline 9 & I & nationalities & China PR: 中国队 'Team China' \\
\hline 10 & J & miscellaneous & Denmark: Dansk Dynamite 'Danish Dynamite' \\
\hline
\end{tabular}

TABLE 2

FREQUENCY AND PERCENTAGE OF EACH TYPE OF TERMS IN NICKNAMES (ALL NFTS)

\begin{tabular}{lclcc}
\hline No. & Type Code & Type of Terms in Nicknames & $\begin{array}{c}\text { Frequency } \\
\text { of Type }\end{array}$ & $\begin{array}{c}\text { Percentage } \\
\text { of Type }\end{array}$ \\
\hline 1 & E & animals & 107 & 22.4 \\
2 & C & colors & 88 & 18.4 \\
3 & B & humans & 72 & 15.1 \\
4 & H & regions & 54 & 11.3 \\
5 & I & nationalities & 48 & 10.1 \\
6 & A & collective & 42 & 8.8 \\
7 & D & virtues & 31 & 6.5 \\
8 & J & miscellaneous & 15 & 3.1 \\
9 & F & celestial bodies & 12 & 2.5 \\
10 & G & natural phenomena & 8 & 1.7 \\
\hline
\end{tabular}

If the same NFT had more than one nickname, all the nicknames were classified and counted. For example, the Brazil NFT has four nicknames: Canarinha 'Little Canary', Seleção 'The National Squad', Verde-Amarela 'The Green and Yellow', and Esquadrão de Ouro 'The Golden Squad'. If the nickname was composed of more than one term, each term was classified and used for the statistical analyses. For example, Golden Jaguars, the nickname of the Guyana NFT, was considered both color-related and animal-related; therefore, it was included in the tallies for two different onomastic types, represented by type codes $\mathrm{C}$ and E. However, La Albiceleste 'the Sky-Blue and Whites', the nickname of Argentina, was considered to have only one color-related term even though it consists of two colors.

This procedure was followed to classify the 477 terms in the 3 I 5 nicknames of the 2I I NFTs investigated. The percentage of each onomastic type identified in the set of the 477 terms in the nicknames is shown in Table 2.

Afterwards, the 2I I FIFA NFTs were divided into six groups based on the football confederations/associations to which the teams belong. These groups are I) Union of European Football Associations (UEFA); 2) Confederation of North, Central American and Caribbean Association Football (CONCACAF); 
3) Asian Football Confederation (AFC); 4) Confederation of African Football (CAF); 5) South American Football Confederation (CONMEBOL); and 6) Oceania Football Confederation (OFC). The terms contained in the nicknames of all the NFTs for each of the six confederations/associations were first classified. Then, the distribution of type codes for each of the six groups was compared along with the distribution patterns of the NFTs to detect whether there were statistically significant differences.

\section{Results and Discussion}

The first research question was which confederation/association had the most and least frequent use of nicknames. The group with the highest occurrence of nicknames was CONMEBOL. The ten NFTs of this confederation have twenty-one nicknames (i.e. 210\%). Eight of the ten CONMEBOL NFTs have two or more than two nicknames, while the Brazil NFT has four nicknames. By comparison, in CAF, the 54 NFTs have only 62 nicknames (I I $4.8 \%$ ). This result reveals that the African NFTs in FIFA were the least likely to use nicknames. Similarly, in OFC, which is made up of I I FIFA members, we found only I 3 nicknames (I I 8.2\%).

We also studied the use of sports signifiers and found that football was never used in the nicknames, even though the official name of each national football team contains the word football. However, we found the word "soccer" and its cross-linguistic variants in The Soca Warriors (Trinidad and Tobago), Socceroos (Australia), and The Soccer Dolphins (Anguilla). The terms "football" and "soccer" are often used to refer to the same sport in the United Kingdom as well as in many other countries. The two terms refer to two different games in the United States, however.

\section{Distribution of Terms in NFT Nicknames}

It would not have been valid to statistically analyze the within-group distribution of nicknames for all the six FIFA confederation/associations as the minimum number of occurrences was not always reached. For example, CONMEBOL has only ten NFTs, and OFC has only eleven NFTs. For this reason, the statistical analyses were conducted for only four confederations/associations (i.e. UEFA, CONCACAF, AFC, CAF) together with all NFTs. As shown in Table 3, I 2 cells $(24.0 \%)$ had an expected frequency count of less than 5 . The minimum expected count was I.55. For this reason, the Fisher Exact Probability test was used. The results showed that there were statistically significant between-group differences in the type codes (P-Fisher value $<0.00 \mathrm{I}$ ). To control for the possible inflation of familywise error rates, the Bonferroni-corrected pvalues were used for pairwise comparisons. Table 3 presents the frequency counts and percentages for four confederation/associations as well as all of the NFTs. The subscripted letters denote the subset of the group categories with column proportions that do not significantly differ from one another at the .05 level. 
TABLE 3

STATISTICAL TEST RESULTS OF EACH TYPE CODE OF FIVE GROUPS

\begin{tabular}{|c|c|c|c|c|c|}
\hline \multirow[b]{2}{*}{ Code Type } & \multicolumn{5}{|c|}{ Group } \\
\hline & $\begin{array}{c}\text { UEFA } \\
\text { Freq }(\%)\end{array}$ & $\begin{array}{l}\text { CONCACAF } \\
\text { Freq }(\%)\end{array}$ & $\begin{array}{c}\text { AFC } \\
\text { Freq }(\%)\end{array}$ & $\begin{array}{c}\text { CAF } \\
\text { Freq }(\%)\end{array}$ & $\begin{array}{l}\text { ALL NFTs } \\
\text { Freq }(\%)\end{array}$ \\
\hline $\bar{A}$ & $20(16.53)^{a}$ & $6(6.82)^{a b}$ & $8(6.30)^{a b}$ & $2(2.06)^{b}$ & $42(8.81)^{a b}$ \\
\hline B & $12(9.92)^{\mathrm{a}}$ & $25(28.41)^{b}$ & $15(11.81)^{\mathrm{a}}$ & $13(13.40)^{a b}$ & $72(15.09)^{a}$ \\
\hline C & $31(25.62)^{a}$ & $14(15.91)^{a b}$ & $23(18.11)^{a}$ & $5(5.15)^{b}$ & $88(18.45)^{a}$ \\
\hline D & $7(5.79)^{a}$ & $6(6.82)^{a}$ & $9(7.09)^{a}$ & $8(8.25)^{a}$ & $31(6.50)^{a}$ \\
\hline $\mathrm{E}$ & $22(18.18)^{a b}$ & $7(7.95)^{b}$ & $35(27.56)^{\mathrm{ac}}$ & $38(39.18)^{c}$ & $107(22.43)^{\mathrm{a}}$ \\
\hline $\mathrm{F}$ & $0(0.00)^{a}$ & $1(1.14)^{a b}$ & $3(2.36)^{a b}$ & $8(8.25)^{b}$ & $12(2.52)^{a b}$ \\
\hline G & $1(0.83)^{a}$ & $5(5.68)^{a}$ & $0(0.00)^{a}$ & $2(2.06)^{a}$ & $8(1.68)^{a}$ \\
\hline $\mathrm{H}$ & $4(3 \cdot 31)^{a}$ & $13(14.77)^{b}$ & $17(13.39)^{\mathrm{b}}$ & $15(15.46)^{b}$ & $54(11.32)^{\mathrm{ab}}$ \\
\hline I & $20(16.53)^{a}$ & $8(9.09)^{a b}$ & $12(9.45)^{a b}$ & $4(4.12)^{b}$ & $48(10.06)^{a b}$ \\
\hline J & $4(3.31)^{\mathrm{a}}$ & $3(3.41)^{\mathrm{a}}$ & $5(3.94)^{a}$ & $2(2.06)^{a}$ & $15(3.14)^{a}$ \\
\hline
\end{tabular}

Note: For all variables with the same letter $a, b$, the difference is not statistically significant. If two variables have different letters, they are significantly different.

As shown in Table 3, the type codes D, G, J, marked with the same letter a, had no significant statistical difference among the five groups. The type codes marked with different letters (i.e. A, B, C, E, F, H, I) represented the various between-group differences. These comparisons did reveal significant statistical differences between certain groups:

I. collective: UEFA (I6.53) is significantly higher than CAF (2.06);

2. humans: CONCACAF $(28.4 \mathrm{I})$ is significantly higher than UEFA (9.92), AFC (I I.8I), and all NFTs (I 5.09);

3. colors: CAF (5.15) is significantly lower than UEFA (25.62), and AFC (I 8.II);

4. animals: CONCACAF (7.95) is significantly lower than AFC (27.56), CAF (39.18), and all NFTs (22.43);

5. celestial bodies: UEFA (0.00) is significantly lower than CAF (8.25);

6. regions: UEFA (3.3I) is significantly lower than CONCACAF (I4.77), AFC (13.39), and CAF (I 5.46);

7. nationalities: UEFA (I6.53) is significantly higher than CAF (2.06).

As shown in Table 4, UEFA showed a preference for collective and nationalities in their nicknames more than all other associations. CONCACAF favored nicknames with humans the most; AFC and CAF had a special preference for animals; CONMEBOL principally distinguished its teams with colors; and CONMEBOL and OFC never used celestial bodies or natural phenomena in their nicknames.

\section{Special Terms in NFT Nicknames}

According to Franks (1982), the ten most frequently used nicknames for US American college athletic teams are, in decreasing order of popularity, the following: eagles, tigers, cougars, bulldogs, warriors, lions, panthers, Indians, 
TABLE 4

DISTRIBUTION OF CODE TYPES OF ALL GROUPS (PERCENTAGE \%)

\begin{tabular}{|c|c|c|c|c|c|c|c|}
\hline \multirow[b]{2}{*}{ Code Type } & \multicolumn{7}{|c|}{ Group } \\
\hline & UEFA & CONCACAF & AFC & CAF & CONMEBOL & OFC & All NFTs \\
\hline $\bar{A}$ & 16.5 & 6.8 & 6.3 & 2.1 & 12.5 & 15.0 & 8.8 \\
\hline B & 9.9 & 28.4 & 11.8 & 13.4 & 12.5 & 20.0 & 15.1 \\
\hline C & 25.6 & 15.9 & 18.1 & 5.2 & 50.0 & 15.0 & 18.4 \\
\hline D & 5.8 & 6.8 & 7.1 & 8.2 & 0.0 & 5.0 & 6.5 \\
\hline$E$ & 18.2 & 8.0 & 27.6 & 39.2 & 4.2 & 20.0 & 22.4 \\
\hline $\mathrm{F}$ & 0.0 & 1.1 & 2.4 & 8.2 & 0.0 & 0.0 & 2.5 \\
\hline G & 0.8 & $5 \cdot 7$ & 0.0 & 2.1 & 0.0 & 0.0 & 1.7 \\
\hline $\mathrm{H}$ & $3 \cdot 3$ & 14.8 & 13.4 & $15 \cdot 5$ & 12.5 & 10.0 & 11.3 \\
\hline I & 16.5 & 9.1 & 9.4 & 4.1 & 4.2 & 15.0 & 10.1 \\
\hline J & 3.3 & 3.4 & 3.9 & 2.1 & 4.2 & 0.0 & 3.1 \\
\hline
\end{tabular}

wildcats, and bears. As a group, this set of names represents human beings or animals commonly recognized for their strength. By utilizing these symbols, these team names identify themselves with the characteristics considered to be essential for the name-bearing athletic teams (Nuessel I994). In this study, we found that the NFTs also used such terms in their nicknames. However, the ten most frequently used terms for NFTs were somewhat different. In order of decreasing popularity, the top ten elements in the NFT nicknames were the following: Red (28, 5.87\%), Team (26, 5.45\%), National (22, 4.6I\%), Boy (2I, $4.40 \%)$, Blue (20, 4.19\%), Lion (20, 4.19\%), White (18, 3.77\%), Star (13, $2.73 \%$ ), Green (I3, 2.73\%), and Warrior (I I, 2.3 I \%). According to our findings, colors were more prominent for the NFTs nicknames than colors in Franks' research (Franks I982). This was not the only difference found, however. In the US college athletic teams investigated by Franks (1982), the most common element in the sport teams' nicknames was eagles. However, in the current investigation of NFTs, eagle (9) was not as much preferred as lion (20). Another difference between the findings of this study and Franks (I982) was that lion (I2) was much more frequently used than tiger (4).

It is open to speculation why lion was more popular than tiger in the NFT nicknames. Perhaps the difference lies in the fact that lions are strong animals that attack together in a group on the grassland - like football players who collectively seek to vanquish their opponents on a grass turf. Tigers are, by contrast, solitary hunters that stealthily ambush their prey. In this respect, it is interesting that the football teams in this study presented themselves, onomastically-speaking, as being more similar to lions than tigers.

Lions are also popular symbols for strength, nobility, and stateliness in cultures across Europe, Asia and Africa. The international popularity of these positive associations may also help to explain why lion appeared in the nicknames of many NFTs. Looking at the different groupings, we found lion in the nicknames of nine out of 46 countries (19.6\%) in AFC; four out of 54 countries $(7.4 \%)$ in CAF; and six out of 55 countries (10.9\%) in UEFA. However, lion 
TABLE 5

NICKNAMES WITH LION

\begin{tabular}{llll}
\hline No. & \multicolumn{1}{c}{ Country } & \multicolumn{1}{c}{ Nicknames } & Confederation \\
\hline 1 & Afghanistan & The Lions of Khorasan & AFC \\
2 & Iran & The Iranian Lions & AFC \\
3 & Iran & Lion Hearts & AFC \\
4 & Iraq & Lions of Mesopotamia & AFC \\
5 & Myanmar & Asian Lions & AFC \\
6 & Palestine & Lions of Canaan & AFC \\
7 & Singapore & The Lions & AFC \\
8 & Sri Lanka & Golden Lion & AFC \\
9 & Tajikistan & The Persian Lions & AFC \\
10 & Cameroon & The Indomitable Lions & CAF \\
11 & Mauritania & Lions of Chinguetti & CAF \\
12 & Morocco & Atlas Lions & CAF \\
13 & Senegal & The Lions of Teranga & CAF \\
14 & Cuba & Lions of the Caribbean & CONCACAF \\
15 & Bulgaria & The Lions & UEFA \\
16 & Czech Republic & The Czech Lions & UEFA \\
17 & England & The Three Lions & UEFA \\
18 & Luxembourg & The Red Lions & UEFA \\
19 & North Macedonia & Red Lions & UEFA \\
20 & Norway & The Lions & UEFA \\
\hline
\end{tabular}

never appeared in two confederations: CONMEBOL, and OFC, as shown in Table 5 .

Although the popularity of the lion was to be expected, what confused us was the fact that eagle appeared more frequently than tiger (4), especially in CAF. This was not the only area of confusion, however.

Nuessel (1994) noted that the percentage of US college teams that bear the name warrior in their nicknames was $32.2 \%$. However, this was not the case for our study. In fact, no NFT nickname included warrior in UEFA, and CONMEBOL, though knight, an equivalent of warrior in Europe, did appear in the nickname of the Malta NFT. Curiously, warrior did exist in eleven nicknames of NFTs from other continents. As shown in Table 6, four warriors were from AFC, three from CAF, another three from CONCACAF, and one from OFC. It may be that the use of warrior in US athletic nicknames reflects a view that football games are viewed as wars or fights. Whatever the case may be, such cross-cultural differences in the use of warrior in athletic nicknames is worthy of further investigation.

Just as warrior appears to be culturally marked, so too seemed to have been the use of dragon. This word was primarily used in Asian countries or regions-specifically in East Asia (China PR), South Asia (Bhutan), and Southeast Asia (Vietnam). Outside of Asia, dragon also featured in team nicknames from Southeast Europe (i.e. Bosnia and Herzegovina) and Northwest Europe (Wales), as shown in Table 7.

Although dragon was found in many different countries, the images and beliefs about this mythical creature vary by region and culture. In western cultures, since the High Middle Ages, dragons have often been depicted as winged, horned, four-legged, and fire-breathing creatures. By contrast, in eastern cultures, they are usually 
TABLE 6

NICKNAMES WITH WARRIOR

\begin{tabular}{llll}
\hline No. & \multicolumn{1}{c}{ Country } & \multicolumn{1}{c}{ Nicknames } & Confederation \\
\hline 1 & Cambodia & Angkor Warriors & AFC \\
2 & South Korea & Taegeuk Warriors & AFC \\
3 & Turkmenistan & Karakum Warriors & AFC \\
4 & Vietnam & The Golden Star Warriors & AFC \\
5 & Algeria & The Desert Warriors & CAF \\
6 & Namibia & Brave Warriors & CAF \\
7 & Zimbabwe & The Warriors & CAF \\
8 & Anguilla & The Rainbow Warriors & CONCACAF \\
9 & Bermuda & Gombey Warriors & CONCACAF \\
10 & Trinidad and Tobago & The Soca Warriors & CONCACAF \\
11 & Tahiti & The Steel Warriors & OFC \\
\hline
\end{tabular}

TABLE 7

NICKNAMES WITH DRAGON

\begin{tabular}{llll}
\hline No. & \multicolumn{1}{c}{ Country } & Nicknames & Confederation \\
\hline 1 & Bhutan & Dragon Boys & AFC \\
2 & China PR & Team Dragon & AFC \\
3 & Vietnam & Golden Dragons & AFC \\
4 & Bosnia and Herzegovina & The Dragons & UEFA \\
5 & Wales & The Dragons & UEFA \\
\hline
\end{tabular}

imagined as wingless, four-legged, serpentine creatures with unusual intelligence and power. In the East, dragons often carry strong positive connotations. In the West, the associations are more ambiguous, ranging from dangerous to demonic.

Similar ambiguity was found in another name element: devil. It has been reported that nicknames like Blue Devils are negative, anti-Christian, nicknames that are frequently unwelcomed by parents (Deardorff I992). However, the South Korean and Vietnamese NFTs of AFC, the Belgian NFT of UEFA, as well as the Congolese NFT from CAF are all called the Red Devils. In this sports context, it may be that these negative associations are somewhat ameliorated. The same has been conjectured of other potentially offensive team names. Roback (I944), Spears (I982), and Nuessel (I994) have all pointed out that the name Canuck is extremely pejorative. In the United States, this term is considered by many to be extremely offensive. This sentiment is especially strong among Canadians from Quebec who live in New England in the United States. Nevertheless, the term Canuck is one of the nicknames of the Canadian NFT. More research is required to explain this seeming contradiction.

\section{Summary and Concluding Remarks}

This preliminary study has addressed the 3 I 5 nicknames of the 2I I FIFA national football teams (NFTs). This investigation made the following discoveries: I) 
nicknames are the most frequently used in CONMEBOL, and the least in CAF; 2) the sport identifier "football" is never used in nicknames and "soccer" is only rarely used; 3 ) the three onomastic categories of virtues, natural phenomena, and miscellaneous showed no statistical difference among NFTs; 4) the seven onomastic categories of collective, humans, colors, animals, celestial bodies, regions, and nationalities showed significant statistical differences among NFTs; and 5) the use of specific terms such as lion, warrior and dragon in nicknames are culturally different.

It is reasonable to assume that the nicknames of NFTs may be strongly influenced by the individual development of the NFTs. However, we believe that an equal if not even more important factor in nicknaming involves the varying cultural history of each team. The Three Lions of England, for example, have the symbol of three blue lions passantguardant. This image was once the emblem of King Richard I, who reigned from I I 89 to I I99. Os Navegadores 'The Navigators' of the Portuguese NFT comes from the nation's previous nautical dominance. The nickname of the Australian NFT, The Socceroos, is a blending of "soccer" and "kangaroos", the unofficial national symbol. By the same token, it is easy to see where the Panamanian and Egyptian NFTs obtained their nicknames: Los Canaleros 'The Canal Men' and الفراعنة 'The Pharaohs'. In each of these cases, the cultural motivation for the NFT nickname is transparent to many outsiders. In other instances, insider cultural knowledge is required. For example, the nickname of the NFT from South Korea is 태극전사 'Taegeuk Warriors'. Originating from China's concept of "Yin and Yang”, Taegeuk represents spiritual balance in Korean culture. To fans unaware of this fact, the NFT nickname is an enigma.

As has been shown here, nicknames are the manifestation of subtle and profound geographical, historical, and cultural difference. We have to admit that we are not able to work out the exact reasons why the NFT nicknames had such significant differences in their composition. However, it is our hope that by sharing our thoughts and research, we might inspire onomasiologists from other continents to conduct more in-depth investigation of the issues raised here. Indeed, the NFT nicknames are so linguistically and culturally diverse that far more detailed, comprehensive studies are needed. It is hoped that this initial foray into these nicknames of NFTs will inspire more academic research and discussion at both the continental and intercontinental levels.

\section{Disclosure statement}

No potential conflict of interest was reported by the author(s).

\section{Funding}

This work was supported by the China Scholarship Council under Grant [201 808420043 ].

\section{ORCID}

Wang Feng (D) http://orcid.org/oooo-0oo2-3284-5046 


\section{Bibliography}

Deardorff, Julie. I992. "School Nicknames Become Name-Calling to Some.” Chicago Tribune, September 4: I4. Franks, Ray. I982. "What's in a Nickname?" In Naming the Jungle of College Athletic Mascots. Amarillo, TX: Ray Franks Publishing Ranch.

Guirao, Immaculada Arboleda. 2017. Full Names vs. Nicknames: Reactions in Spanish and English. SaintDenis: Connaissances et Savoirs.

Harre, R. I980. "What's in a Nickname?" Psychology Today, January 3: 78-79, 8 I-84.

Lavric, Eva., et al. 2008. eds. The Linguistics of Football. Tübingen: Gunter Narr Verlag.

Leslie, Paul L., and James K. Skipper. I990. "Toward a Theory of Nicknames: A Case for SocioOnomastics." Names 38, no. 4: 273-282.

Lieb, Frederick. 1943. "Dizzy, Lippy, Babe or Cy Give an Image to the Eye." The Sporting News, November I 8 .

McBride, Joseph. I980. High and Inside: The Complete Guide to Baseball Slang. New York: Warner Books. Nuessel, Frank. I994. "Objectionable Sport Team Designations.” Names 42, no. 2: IoI-I I9.

Roback, A. I944. A Dictionary of Ethnic Slurs (Ethnophaulisms) with a Supplementary Essay on Aspects of Ethnic Prejudice. Cambridge, MA: Sci-Art Publishers [Reprinted 1979 by Maledicta Press, Waukesha, WI].

Skipper, James. I985. "Nicknames of Notorious American Twentieth-Century Deviants: The Decline of the Folk Hero Syndrome." Deviant Behavior 6, no. I: 99-I I4.

Spears, Richard A. I982. Slang and Euphemism. abridged ed. New York: Signet.

Wikipedia. 20I9a. "List of Men's National Association Football Teams.” Wikipedia. <https://en.wikipedia. org/wiki/List_of_men\%27s_national_association_football_teams >. (accessed Jan 9, 2020).

Wikipedia. 20I9b. "List of National Association Football Teams by Nickname." Wikipedia. https://en. wikipedia.org/wiki/List_of_national_association_football_teams_by_nickname (accessed Jan IO, 2020).

Wilson, Brenda S., and James K. Skipper. I990. "Nicknames and Women Professional Baseball Players." Names 38, no. 4: 305-322.

Wood, Robert. 2008. "Football (Soccer) Team Nicknames.” Topend Sports Website. <https://www.topendsports.com/sport/soccer/team-nicknames.htm> (accessed Jan 9, 2020).

\section{Notes on contributors}

Dr. Wang Feng is an Associate Professor in the School of Foreign Studies, Yangtze University, and a Post-Doctoral Researcher in the School of Foreign Languages and Cultures, Nanjing Normal University. His research interests include translation studies, intercultural communication, foreign language education, and onomastics.

Ms. Zhang Shuyue is a graduate student in the School of Foreign Studies, Yangtze University. Her research interests include translation studies and intercultural communication.

Dr. Chen Cheng is an Associate Professor in the School of Foreign Languages, Shanghai Ocean University. Her research interests include translation studies, intercultural communication, and foreign language education.

Correspondence to: Dr. Wang Feng, School of Foreign Studies, Yangtze University, No. I, Nanhuan Road, Jingzhou, Hubei, China, 434023. Email: wangfeng@yangtzeu.edu.cn 


\section{Appendix}

\section{Nicknames of National Football Teams of FIFA}

AFC (ASIAN FOOTBALL CONFEDERATION).

\begin{tabular}{|c|c|}
\hline NFT (46) & Nickname (76) \\
\hline Afghanistan & Širhâi Khorasan 'The Lions of Khorasan' \\
\hline Australia & Socceroos \\
\hline Bahrain & 'The Red Wolves’ \\
\hline Bangladesh & $\begin{array}{l}\text { Bengal Tigers } \\
\text { Red and Green }\end{array}$ \\
\hline Bhutan & Dragon Boys \\
\hline Brunei Darussalam & Tebuan 'The Hornets' \\
\hline Cambodia & $\begin{array}{c}\text { Krom Chumreswcheit 'The National Team’ } \\
\text { 'Angkor Warriors' } \\
\text { 'Kouprey Kampuchea' }\end{array}$ \\
\hline China PR & $\begin{array}{l}\text { 龙之队 ‘Team Dragon’ } \\
\text { 中国队 ‘Team China’ }\end{array}$ \\
\hline Chinese Taipei & 中华队 ‘Team Zhonghua’ \\
\hline Guam & Matao 'a social class in ancient Chamorro society' \\
\hline Hong Kong & 勁揪 ‘The Strength’ \\
\hline India & Blue Tigers \\
\hline Indonesia & $\begin{array}{l}\text { Merah Putih 'The Red and White' } \\
\text { Tim Garuda 'The Garuda Team' }\end{array}$ \\
\hline Iran & $\begin{array}{l}\text { ت 'The National Team' } \\
\text { Persian Stars } \\
\text { Shiran e Iran 'The Iranian Lions' } \\
\text { Shirdelan 'Lion Hearts' } \\
\text { Princes of Persia } \\
\text { 'The Cheetahs' }\end{array}$ \\
\hline $\begin{array}{l}\text { Iraq } \\
\text { Japan }\end{array}$ & 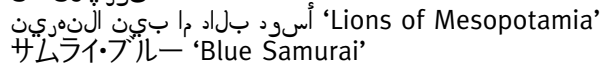 \\
\hline Jordan & 'The Chivalrous' \\
\hline Kuwait & 'The Blues’ الذّرق 'The \\
\hline Kyrgyzstan & Ак шумкарлар ‘The White Falcons’ \\
\hline Laos & 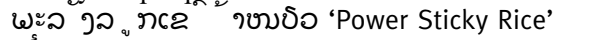 \\
\hline Lebanon & 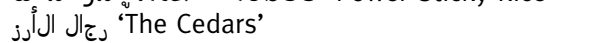 \\
\hline Malaysia & $\begin{array}{l}\text { Harimau Malaya 'Malayan Tiger' } \\
\text { Skuad Kebangsaan 'National Team' }\end{array}$ \\
\hline Maldives & Red Snapper \\
\hline Macau & The Greens \\
\hline Mongolia & Хөх Чононууд ‘Blue Wolves’ \\
\hline Myanmar & Asian Lions \\
\hline Nepal & The Gorkhalis \\
\hline North Korea & 천리마 ‘Thousand-Mile Horse’ \\
\hline Oman & 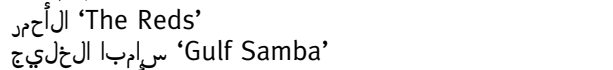 \\
\hline Palestine & 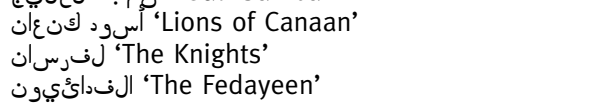 \\
\hline Pakistan & بֶ. "Pak Shaheen’ \\
\hline Philippines & Azkals 'Street Dogs' \\
\hline Qatar & 'The Maroons’ \\
\hline Saudi Arabia & 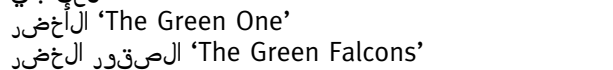 \\
\hline Singapore & The Lions \\
\hline South Korea & $\begin{array}{l}\text { 붉은 악마 ‘Red Devils’ } \\
\text { 태극전사 ‘Taegeuk Warriors’ } \\
\text { 아시아의 호랑이 ‘Tigers of Asia’ }\end{array}$ \\
\hline
\end{tabular}


(CONTINUED).

\begin{tabular}{|c|c|}
\hline$\overline{N F T}(46)$ & Nickname (76) \\
\hline Sri Lanka & 'Golden Lion' \\
\hline Syria & نQasioun Eagles’ \\
\hline Tajikistan & Шерхои форсЙ 'The Persian Lions' \\
\hline & дастаи миллЙ ‘The National Team’ \\
\hline Thailand & ช้างศึก 'War Elephants' \\
\hline Timor-Leste & $\begin{array}{l}\text { O Sol Nascente 'The Rising Sun' } \\
\text { Pequena Nação do Samba 'The Little Samba Nation' } \\
\text { El Lafaek 'The Crocodiles' }\end{array}$ \\
\hline Turkmenistan & $\begin{array}{l}\text { Emerald } \\
\text { Greens } \\
\text { Karakum Warriors } \\
\text { The Akhal-Teke Horses }\end{array}$ \\
\hline United Arab Emirates & $\begin{array}{l}\text { Eyal Zayed 'Sons of Zayed' } \\
\text { Al Abyad 'The Whites' }\end{array}$ \\
\hline Uzbekistan & $\begin{array}{l}\text { Oq bo'rilar 'White Wolves' } \\
\text { Turonliklar 'Turanians' } \\
\text { Osiyo Italiyasi 'Asian Italy' } \\
\text { Humo qushlari ‘Huma birds' }\end{array}$ \\
\hline Vietnam & $\begin{array}{l}\text { Rồng Vàng 'Golden Dragons' } \\
\text { Chiền Binh Sao Vàng 'The Golden Star Warriors' }\end{array}$ \\
\hline Yemen & $\begin{array}{l}\text { 'The Happy Yemen’ } \\
\text { 'The Red Devils’ } \\
\text { اليمنين 'The Qahtani Arabs’ }\end{array}$ \\
\hline
\end{tabular}

CAF (CONFEDERATION OF AFRICAN FOOTBALL).

\begin{tabular}{|c|c|}
\hline NFT (54) & Nickname (62) \\
\hline Algeria & 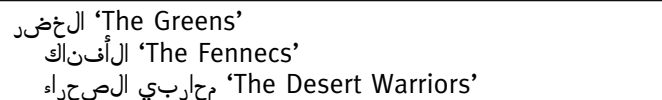 \\
\hline Angola & Palancas Negras 'Giant Sable Antelopes' \\
\hline Benin & Les Écureuils 'The Squirrels' \\
\hline Botswana & Dipitse 'The Zebras' \\
\hline Burkina Faso & Les Étalons ‘The Stallions’ \\
\hline Burundi & Les Hirondelles 'The Swallows' \\
\hline Cameroon & Les Lions Indomptables 'The Indomitable Lions' \\
\hline Cape Verde & $\begin{array}{l}\text { Tubarões Azuis 'Blue Sharks' } \\
\text { Crioulos 'Creoles' }\end{array}$ \\
\hline Central African Republic & Les Fauves 'The Beasts' \\
\hline Chad & Les Sao 'The Sao \\
\hline Comoros & Les Coelecantes 'The Coelacanths' \\
\hline Congo & Diables Rouges 'Red Devils’ \\
\hline DR Congo & Les Léopards 'The Leopards' \\
\hline Ivory Coast & Les Éléphants 'The Elephants' \\
\hline Djibouti & Riverains de la Mer Rouge 'Shoremen of the Red Sea' \\
\hline Egypt & 'The Pharaohs’ الفراعنة 'The \\
\hline Equatorial Guinea & Nzalang Nacional 'National Thunder' \\
\hline Eritrea & 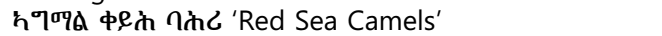 \\
\hline Eswatini & Sihlangu Semnikati 'King's Shield' \\
\hline Ethiopia & Walia ibex \\
\hline Gabon & Les Panthères 'The Panthers’ \\
\hline Gambia & The Scorpions \\
\hline Ghana & Black Stars \\
\hline Guinea & Syli Nationale 'National Elephants' \\
\hline Guinea-Bissau & Djurtus ‘The African Wild Dog' \\
\hline Kenya & Harambee Stars \\
\hline
\end{tabular}


(CONTINUED).

\begin{tabular}{|c|c|}
\hline NFT (54) & Nickname (62) \\
\hline Lesotho & Likuena 'Crocodiles' \\
\hline Liberia & Lone Star \\
\hline Libya & 'The Mediterranean Knights’ فرسان المتوسط \\
\hline Madagascar & Les Baréa 'A Species of Zebu' \\
\hline Malawi & The Flames \\
\hline Mali & Les Aigles 'The Eagles' \\
\hline Mauritania & الجرابطون 'Lions of Chinguetti’ \\
\hline Mauritius & $\begin{array}{l}\text { المدابطون 'The Almoravids’ } \\
\text { Club M } \\
\text { The Dodos }\end{array}$ \\
\hline Morocco & 'Atlas Lions’ ' أسود الأطالس ‘ \\
\hline Mozambique & Os Mambas 'The Mambas' \\
\hline Namibia & Brave Warriors \\
\hline Niger & Ménas 'A Species of Antelope' \\
\hline Nigeria & Super Eagles \\
\hline Rwanda & Amavubi 'The Wasps' \\
\hline São Tomé and Príncipe & $\begin{array}{l}\text { Seleção dos Falcões e Papagaios 'The Falcons and True Parrots Team' } \\
\text { Os Verde-Amarelos 'The Green-Yellows' }\end{array}$ \\
\hline Senegal & Les Lions de la Téranga 'The Lions of Teranga' \\
\hline Seychelles & The Pirates \\
\hline Sierra Leone & Leone Stars \\
\hline Somalia & Ocean Stars \\
\hline South Africa & Bafana Bafana 'Boys, Boys’ \\
\hline South Sudan & Bright Stars \\
\hline Sudan & 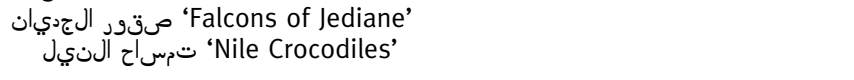 \\
\hline Tanzania & $\begin{array}{l}\text { Kilimanjaro Stars } \\
\text { Taifa Stars }\end{array}$ \\
\hline Togo & Les Éperviers 'The Sparrow hawks' \\
\hline Tunisia & 'Eagles of Carthage’ \\
\hline Uganda & The Cranes \\
\hline Zambia & Chipolopolo 'The Copper Bullets' \\
\hline Zimbabwe & The Warriors \\
\hline
\end{tabular}

CONCACAF (CONFEDERATION OF NORTH, CENTRAL AMERICAN, AND CARIBBEAN ASSOCIATION FOOTBALL).

\begin{tabular}{ll}
\hline NFT (35) & \multicolumn{1}{c}{ Nickname (57) } \\
\hline Anguilla & The Rainbow Warriors \\
The Soccer Dolphins & The Benna Boys "Benna" is a form of local music \\
Antigua and Barbuda & The Wadadi Boyz "Wadadi” is a local dance \\
Aruba & La Selección 'The Selection' \\
Rahamas & Rake \& Scrape Boys (Rake-and-scrape is local music) \\
& Bahamian Slayersz 'The Baha Boyz' \\
Barbados & Bajan Tridents \\
Belize & The Unbelizeables \\
& The Jaguars \\
Bermuda & Gombey Warriors \\
British Virgin Islands & The Nature Boyz \\
Canada & The Canucks \\
Cayman Islands & Les Rouges 'The Reds' \\
Costa Rica & The Turtles
\end{tabular}


(CONTINUED).

\begin{tabular}{|c|c|}
\hline NFT (35) & Nickname (57) \\
\hline & $\begin{array}{l}\text { The Ticos 'Los Ticos' } \\
\text { La Sele 'The Selection' } \\
\text { Los Matacampeones 'The Champion Killers' }\end{array}$ \\
\hline Cuba & Leones del Caribe 'Lions of the Caribbean' \\
\hline Curaçao & The Blue Stars \\
\hline Dominican & Los Pericos 'The Parrots' \\
\hline Dominican Republic & Los Quisqueyanos the Quisqueyanos is an island \\
\hline El Salvador & $\begin{array}{l}\text { La Seleccion 'The Selection' } \\
\text { Los Cuzcatlecos 'The Cuzcatlecos' } \\
\text { La azul y Blanco 'White and Blue' }\end{array}$ \\
\hline Grenada & Spice Boys \\
\hline Guadeloupe & $\begin{array}{l}\text { Guys of Guadeloupe } \\
\text { Gwada Boys }\end{array}$ \\
\hline Guatemala & $\begin{array}{l}\text { Los Chapines 'The Chapines' } \\
\text { La Furia Azul 'The Blue Fury' } \\
\text { La Bicolor 'The Bicolor' }\end{array}$ \\
\hline Guyana & Golden Jaguars \\
\hline Haiti & $\begin{array}{l}\text { Les Bicolores 'The Bicolor' } \\
\text { Les Grenadiers 'The Grenadiers' } \\
\text { Le Rouge et Bleu 'The Red \& Blue' } \\
\text { La Sélection Nationale 'The National Selection' }\end{array}$ \\
\hline Honduras & $\begin{array}{l}\text { Los Catrachos 'The Catrachos' } \\
\text { La Bicolor 'The Bicolor' } \\
\text { The H 'La H' }\end{array}$ \\
\hline Jamaica & Reggae Boyz \\
\hline Mexico & El Tri 'The Tricolor' \\
\hline Montserrat & Emerald Boys \\
\hline Nicaragua & $\begin{array}{l}\text { The Pinolero } \\
\qquad \text { La Azul y Blanco 'The Blue \& White' }\end{array}$ \\
\hline Panama & $\begin{array}{l}\text { Los Canaleros 'The Canal Men' } \\
\text { La Marea Roja 'The Red Tide' }\end{array}$ \\
\hline Puerto Rico & El Huracán Azul 'The Blue Hurricane' \\
\hline Saint Kitts and Nevis & The Sugar Boyz \\
\hline Saint Lucia & The Piton \\
\hline Saint Vincent and the Grenadines & Vincy Heat \\
\hline Suriname & $\begin{array}{l}\text { De Natio 'The National Selection' } \\
\text { Suriboys }\end{array}$ \\
\hline Trinidad and Tobago & The Soca Warriors \\
\hline Turks and Caicos Islands & TCI Team \\
\hline United States & $\begin{array}{l}\text { The Stars and Stripes } \\
\text { The Yanks }\end{array}$ \\
\hline US Virgin Islands & The Dashing Eagle \\
\hline
\end{tabular}


CONMEBOL (CONFEDERACIÓN SUDAMERICANA DE FÚTBOL).

\begin{tabular}{|c|c|}
\hline NFT (10) & Nickname (21) \\
\hline Argentina & La Albiceleste 'The Sky-Blue and Whites' \\
\hline Bolivia & La Verde 'The Green’ \\
\hline Brazil & $\begin{array}{l}\text { Canarinha 'Little Canary' } \\
\text { Seleção 'The National Squad' } \\
\text { Verde-Amarela 'The Green and Yellow' } \\
\text { Esquadrão de Ouro 'The Golden Squad' }\end{array}$ \\
\hline Chile & $\begin{array}{l}\text { La Roja 'The Red One' } \\
\text { El equipo de todos 'The team of everyone' }\end{array}$ \\
\hline Colombia & $\begin{array}{l}\text { Los Cafeteros 'The Coffee Growers' } \\
\text { La Tricolor 'The Tricolors' }\end{array}$ \\
\hline Ecuador & $\begin{array}{l}\text { Los Amarillos 'The Yellows' } \\
\text { The Tricolour }\end{array}$ \\
\hline Paraguay & $\begin{array}{l}\text { La Albirroja ‘The White-Red’ } \\
\text { Los Guaraníes 'The Guaranies' }\end{array}$ \\
\hline Peru & $\begin{array}{l}\text { La Blanquirroja 'The White-Red' } \\
\text { Los Incas 'The Incas' }\end{array}$ \\
\hline Uruguay & $\begin{array}{l}\text { La Celeste 'The Sky Blue’ } \\
\text { Los Charrúas 'The Charrúa' }\end{array}$ \\
\hline Venezuela & $\begin{array}{l}\text { Los Llaneros 'The Plainsmen' } \\
\text { La Vinotinto 'The Burgundy' } \\
\text { La Remolacha Mecanica 'The Clockwork Beet' }\end{array}$ \\
\hline
\end{tabular}

OFC (OCEANIA FOOTBALL CONFEDERATION).

\begin{tabular}{|c|c|}
\hline NFT (11) & Nickname (13) \\
\hline American Samoa & $\begin{array}{l}\text { Au Fili 'The National Team' } \\
\text { The Boys from the Territory }\end{array}$ \\
\hline Cook Islands & $\begin{array}{l}\text { Te Kapa Motu 'The National Team' } \\
\text { The Green and Whites }\end{array}$ \\
\hline Fiji & Bula Boys \\
\hline New Caledonia & Les Cagous 'The Kagus' \\
\hline New Zealand & All Whites \\
\hline Papua New Guinea & Cuscus \\
\hline Samoa & Manumea, a "Manumea" is a native bird \\
\hline Solomon Islands & Bonitos \\
\hline Tahiti & Toa Aito 'The Steel Warriors' \\
\hline Tonga & Timi Fakafomua 'The National Team' \\
\hline Vanuatu & The Men in Black and Gold \\
\hline
\end{tabular}


UEFA (UNION OF EUROPEAN FOOTBALL ASSOCIATIONS).

\begin{tabular}{|c|c|}
\hline NFT (55) & Nickname (85) \\
\hline Albania & $\begin{array}{l}\text { Kuq e Zinjtë 'The Red and Blacks' } \\
\text { Shqiponjat 'The Eagles' }\end{array}$ \\
\hline Andorra & The Tricolors \\
\hline Armenia & Zuılufulyufi 'The Collective Team’ \\
\hline Austria & $\begin{array}{l}\text { Das Team 'The Team' } \\
\text { Burschen 'The Boys' } \\
\text { Unsere Burschen 'Our Boys' }\end{array}$ \\
\hline Azerbaijan & Milli 'The National' \\
\hline Belarus & Белыя крылы 'The White Wings' \\
\hline Belgium & De Rode Duivels 'The Red Devils' \\
\hline Bosnia and Herzegovina & $\begin{array}{l}\text { Zmajevi 'The Dragons' } \\
\text { Zlatni ljiljani 'The Golden Lilies' }\end{array}$ \\
\hline Bulgaria & Иъвовете ‘The Lions' \\
\hline Croatia & $\begin{array}{l}\text { Vatreni 'The Blazers' } \\
\text { Kockasti 'The Chequered Ones' }\end{array}$ \\
\hline Cyprus & I Galanolefki 'The White and Blues' \\
\hline Czech Republic & $\begin{array}{l}\text { Lokomotiva 'The Locomotive' } \\
\text { češki lavovi 'The Czech Lions' } \\
\text { Narodni Tym 'The National Team' }\end{array}$ \\
\hline Denmark & $\begin{array}{l}\text { Dansk Dynamite 'Danish Dynamite' } \\
\text { De rød-hvide 'The Red and White' }\end{array}$ \\
\hline England & The Three Lions \\
\hline Estonia & Sinisärgid 'Blueshirts' \\
\hline Faroe Islands & Landsli $i$ 'The National Team' \\
\hline Finland & Huuhkajat 'The Eagle-owls' \\
\hline France & $\begin{array}{l}\text { Les Bleus 'The Blues' } \\
\text { Les Tricolores or L'Equipe Tricolore 'The Tri-color Team' } \\
\text { Brazilians of Europe }\end{array}$ \\
\hline $\begin{array}{l}\text { Georgia } \\
\text { Germany }\end{array}$ & 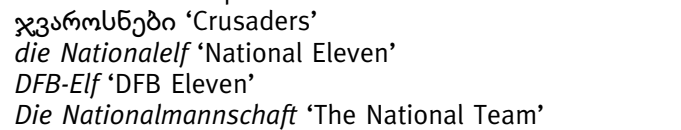 \\
\hline $\begin{array}{l}\text { Gibraltar } \\
\text { Greece }\end{array}$ & $\begin{array}{l}\text { Team } 54 \\
\text { Piratiko 'Pirate Ship' } \\
\text { Ethniki 'National' } \\
\text { I Galanolefki 'Sky Blue-White' }\end{array}$ \\
\hline Hungary & $\begin{array}{l}\text { The National Eleven } \\
\text { Magyarok 'Magyars' }\end{array}$ \\
\hline Iceland & Strákarnir okkar 'Our Boys' \\
\hline Israel & 'The Blues and Whites' הכחולים-לבנים ' \\
\hline Italy & $\begin{array}{l}\text { Gli Azzurri 'The Blues' } \\
\text { La Nazionale 'The National Team' }\end{array}$ \\
\hline Kazakhstan & аршығалар 'The Hawks' \\
\hline Kosovo & Dardanët 'Dardanians' \\
\hline Latvia & 11 vilki '11 Wolves' \\
\hline Liechtenstein & The Blues-Reds \\
\hline Lithuania & Rinktine 'National Team' \\
\hline Luxembourg & Die Roten Löwen 'The Red Lions' \\
\hline Malta & $\begin{array}{l}\text { Knights of Malta } \\
\text { Homor 'Reds' } \\
\text { Falcons }\end{array}$ \\
\hline Moldova & Selectionata 'The Selection' \\
\hline Montenegro & Hrabri Sokoli 'The Brave Falcons' \\
\hline Netherlands & $\begin{array}{l}\text { Oranje 'Orange' } \\
\text { Clockwork Orange } \\
\text { Holland } \\
\text { The Flying Dutchmen }\end{array}$ \\
\hline
\end{tabular}


(CONTINUED).

\begin{tabular}{|c|c|}
\hline NFT (55) & Nickname $(85)$ \\
\hline North Macedonia & $\begin{array}{l}\text { Црвени Рисови 'Red Lynxes' } \\
\text { Црвени Иавови ‘Red Lions' }\end{array}$ \\
\hline Northern Ireland & $\begin{array}{l}\text { Green and White Army } \\
\text { Norn Iron }\end{array}$ \\
\hline Norway & Løvene 'The Lions' \\
\hline Poland & $\begin{array}{l}\text { Bia o-czerwoni 'The White and Red' } \\
\text { Or y 'The Eagles' }\end{array}$ \\
\hline Portugal & $\begin{array}{l}\text { Selecção das Quinas 'The Selection of Quinas' } \\
\text { Os Navegadores 'The Navigators' }\end{array}$ \\
\hline Republic of Ireland & $\begin{array}{l}\text { Na buachailli i nglas 'The Boys in Green' } \\
\text { The Green Army }\end{array}$ \\
\hline Romania & Tricolorii 'The Tricolours' \\
\hline Russia & Сборная 'The National Team' \\
\hline San Marino & La Serenissima 'The Most Serene' \\
\hline Scotland & $\begin{array}{l}\text { The Tartan Terriers } \\
\text { The Tartan Beasts }\end{array}$ \\
\hline Serbia & Орлови 'The Eagles' \\
\hline Slovakia & $\begin{array}{l}\text { Sokoli 'The Falcons' } \\
\text { Repre 'The Representatives' }\end{array}$ \\
\hline Slovenia & Fantje 'The Boys' \\
\hline Spain & $\begin{array}{l}\text { La Roja 'The Red' } \\
\text { La Furia Roja 'The Red Fury' }\end{array}$ \\
\hline Sweden & Blaggult 'The Blue and Yellow' \\
\hline Switzerland & $\begin{array}{l}\text { Nati 'National Team' } \\
\text { Rossocrociati 'Red Crosses' }\end{array}$ \\
\hline Turkey & Ay-Yıldızlılar 'The Crescent-Stars' \\
\hline Ukraine & $\begin{array}{l}\text { Головна команда 'The Main Team' } \\
\text { Жовто-Сині 'The Yellow and Blue' }\end{array}$ \\
\hline Wales & Y Dreigiau 'The Dragons' \\
\hline
\end{tabular}

